\title{
ANALISIS KEPENTINGAN RUSIA DAN TURKI DALAM KONFLIK ARMENIA-AZERBAIJAN PADA TAHUN 2020
}

\author{
ANALYSIS OF THE INTEREST OF RUSSIA AND TURKEY IN CONFLICT \\ ARMENIA-AZERBAIJAN IN 2020
}

\author{
Ahmad Zainal Mustofa \\ Pascasarjana UIN Sunan Kalijaga Yogyakarta \\ E-mail : m.ahmadzainal@gmail.com
}

\begin{abstract}
ABSTRAK
Artikel ini menjelaskan tentang kepentingan Rusia dan Turki dalam konflik antara Armenia dan Azerbaijan. Penelitian ini menekankan pada konsep aliansi untuk mengulas motif kepentingan Rusia dan Turki. Kemudian metode penelitian ini menggunakan penelitian pustaka dengan mengumpukan sumber-sumber yang relevan dengan pembahasan. Adaapun kesimpulan dalam penelitian inia dalah konflik ini pada awalnya terjadi akibat adanya sengketa wilayah NagornoKarabakh yang secara geografis menjadi milik Azerbaijan. Namun karena mayoritas penduduk di wilayah tersebut adalah etnis Armenia, maka mereka berusaha mengambil alih Nagorno-Karabakh dengan di dukung oleh pemerintah Armenia. Konflik ini dimanfaatkan oleh Turki yang mendukung Azerbaijan. Turki mendukung Azerbaijan karena adanya kesamaan bahasa dan budaya serta hubungan politik yang kuat. Kemudian, Rusia memiliki kepentingan terhadap Armenia dan Azerbaijan di bidang ekonomi sebagai pemasok senjata perang bagi kedua negara. Sehingga Rusia menjadi mediator untuk mencari resolusi terbaik dalam konflik kedua negara tersebut.
\end{abstract}

Kata Kunci: Konflik Armenia-Azerbaijan, Nagorno-Karabakh, Aliansi, Resolusi Konflik

\section{ABSTRACT}

This article describes the interests of Russia and Turkey in the conflict between Armenia and Azerbaijan. This study concern to alliance concept to review the motives of the interests of Russia and Turkey. Then the method used is library research by collecting sources relevant to the discussion. The conclusion in this study is that this conflict initially occurred due to the dispute over the NagornoKarabakh region which geographically belongs to Azerbaijan. However, because the majority of the population in the area are ethnic Armenians, they are trying to take over Nagorno-Karabakh with the support of the Armenian government. This conflict was exploited by Turkey who supported Azerbaijan. Turkey supports Azerbaijan because of the common language and culture as well as strong political ties. Then, Russia has an interest in Armenia and Azerbaijan in the economic field as a supplier of weapons of war to both countries. So that Russia becomes a mediator to find the best resolution in the conflict between the two countries.

Keywords: Armenia-Azerbaijan Conflict, Nagorno-Karabakh, Alliance, Conflict Resolution

\section{PENDAHULUAN}

Pada tanggal 27 September 2020, pertempuran besar baru kembali pecah antara Armenia dan Azerbaijan di wilayah Nagorno-Karabakh. Hubungan kedua negara memang 
sedang memanas. Pada bulan-bulan sebelumnya, ketegangan politik antara Armenia dan Azerbaijan telah meningkat. Tercatat sepanjang 12 Juli hingga 16 Juli 2020, Armenia dan Azerbaijan bertukar tembakan artileri di sepanjang perbatasan mereka, sekitar 185 mil sebelah utara Nagorno-Karabakh. Meskipun tidak jelas apa yang sebenarnya memicu konflik Juli lalu, beberapa analis percaya bahwa peristiwa tersebut mencerminkan eskalasi konflik terus menghangat (Welt \& Bowen, 2021).

Perkembangan eskalasi konflik meningkat pada pertengahan Juli ketika militer Azerbaijan dan Armenia dengan penggunaan tank, drone, dan mortir terlibat dalam bentrokan langsung selama beberapa hari di timur laut bagian dari garis depan Armenia-Azerbaijan. Untuk waktu yang singkat dari 12 hingga 16 Juli 2020, bentrokan tersebut mengakibatkan tewasnya lima tentara Armenia dan 16 tentara Azerbaijan, termasuk dua perwira tinggi Azerbaijan. Bangunan di seluruh wilayah mengalami kerusakan yang cukup parah. Keadaan ini memaksa penduduk setempat untuk melarikan diri. Pada bulan-bulan berikutnya, baik Armenia maupun Azerbaijanjan terus saling tuduh provokasi. Puluhan ribu orang menggelar demonstrasi di Azerbaijan setelah bentrokan Juli, mereka menyerukan pemerintah untuk merespon sikap tersebut dengan melakukan skala operasi di wilayah territorial (Ghaplanyan, 2021).

Gencatan senjata yang terjadi antara Armenia dan Azerbaijan ini telah memakan korban dari kedua belah pihak. Keadaan ini juga diperparah dengan penggunaan senjatasenjata berat seperti tank, artileri dan lainnya yang menimbulkan konflik regional dengan skala cukup besar. Baik Armenia maupun Azerbaijan belum menemui kata sepakat berdamai atas konflik Juli 2020 ini. Hal ini dapat memicu konflik-konflik lanjutan dikemudian hari.

Namun, dalam konflik ini terdapat juga peran aktor luar negara yang turut terlibat di dalamnya, yaitu Rusia dan Turki. Tentu saja Rusia dan Turki memiliki kepentingankepentingan dalam konflik Armenia dan Azerbaijan di wilayah Nagorno-Karabakh. Penelitian ini akan mencoba mengulas tentang sejarah konflik Armenia dan Azerbaijan. Kemudian motif kedua negara dalam perang di Nagorno-Karabakh serta kepentingan Rusia dan Turki dalam pusaran konflik tersebut. 
Dalam penelitian ini, penulis mencoba mengeksplor aliansi dalam konflik antara Armenia dan Azerbaijan di Nagorno-Karabakh. Diketahui bahwa Turki merupakan aliansi Azerbaijan dalam konflik tersebut. Sedangkan Armenia merupakan aliansi Rusia. Namun, posisi Rusia tidak condong kepada Armenia saja, tetapi Rusia juga memiliki hubungan baik dengan Azerbaijan. Tentu saja di balik itu semua terdapat kepentingan-kepentingan yang ingin diraih oleh Rusia dan Turki.

\section{KERANGKA TEORITIS}

\subsection{Teori Aliansi}

Teori merupakan pembentukan sejumlah pernyataan-pemyataan tentang perilaku yang rasional berdasarkan motivasi yang mendominasi seperti misalnya power. Power, dianggap sebagai sebuah teori yang akan memberikan suatu deskripsi terhadap perilaku politik yang dilakukan oleh aktor yang bertindak secara rasional, maka dalam hubungan ini perilaku dapat dihubungkan dengan dunia nyata sebagai suatu rangkaian periode sejarah. Hans. J. Morgenthau, menggunakan teori politik berdasarkan fakta sebagai gambaran rasional terhadap politik dan aktornya (Sitepu, 2011). Adapun teori yang digunakan dalam penelitian ini adalah teori neorealisme dengan pendekatan terhadap aliansi.

Sebagai tokoh neorealisme, Waltz nerusaha menempatkan teori realis satu langkah lebih maju dengan menegaskan bahwa hukum-hukum general yang dapat diidentifikasi untuk mrnjrlaskan beragam peristiwa dalam sistem internaisonal. Esensi neorealisme ialah memberikan konsentrasi penuh terhadap struktur dan sistem internasional. Sebagaimana halnya realisme yang mana Hans J. Morgenthau menjadi tokohnya, neorealisme juga melihat balance of power. Namun mereka menempatkan gagasan perimbangan kekuatan tersebut di dalam struktur dari sistem internasional secara general dan bukan hanya berfokus pada unsur negara-negara. Asumsi keseimbangan dalam perspektif neorealisme juga berkontribuasi pada peran yang dimainkan oleh aliansi-aliansi sebagaimana mereka mempengaruhi struktur dari sistem internasional (Bakry, 2017).

Aliansi adalah pengaturan keamanan kolektif antara negara-negara di mana semua anggota aliansi setuju untuk tidak mengancam satu sama lain, untuk menghukum pembelot 
dari perjanjian ini, dan untuk mengancam negara-negara di luar aliansi kapan pun demi kepentingan masing-masing untuk melakukannya. Kenneth Waltz mendifinisikan bahwa aliansi adalah pengaturan formal atau informal untuk kerjasama keamanan antara dua atau lebih negara berdaulat. Selain Waltz, Snyder memandang bahwa aliansi adalah asosiasi formal negara-negara untuk digunakan (atau tidak digunakannya) kekuatan militer yang dimaksudkan baik untuk keamanan atau peningkatan ukuran anggota mereka terhadap negara-negara lain tertentu (Niou \& Ordeshook, 1994). Sebagaimana yang terjadi dalam konflik Armenia dan Azerbaijan. Konflik yang berlangsung di wilayah Nagorno-Karabakh ini terdapat aliansi bagi negara yang bersangkutan. Seperti aliansi Azerbaijan-Turki dan Armenia-Rusia. Namun tidak seperti hubungan Turki yang hangat dengan Armenia, Rusia juga memiliki hubungan baik dengan Azerbaijan.

\section{METODOLOGI PENELITIAN}

Untuk menguraikan langkah demi langkah dalam proses penelitian, maka perlu adanya metode penelitian. Metode penelitian merupakan cara yang digunakan dalam penelitian untuk mencapai tujuan penelitian tertentu. Tujuan tersebut meliputi kegiatan berfikir dan dan berbuat (Kartini, 1996). Penelitian dalam tulisan ini menggunakan model kepustakaan (library research). Model ini menekankan penelitian dengan mengumpulkan berbagai macam informasi yang berasal dari buku-buku, majalah, artikel, dan berbagai sumber yang berkaitan dengan penelitian ini (Mardalis, 2008). Dalam penelitian ini, penulis mencoba mengumpulkan berbagai sumber yang berkaitan dengan konflik Armenia dan Azerbaijan serta kepentingan Rusia dan Turki di dalamnya. Dengan mengolah sumber-sumber kepustakaan tersebut agar bisa menghasilkan penelitian yang informatif baik secara esensial maupun substansial.

\section{HASIL DAN PEMBAHASAN}

\subsection{Sejarah Konflik Armenia-Azerbaijan}

Konflik antara Armenia dan Azerbaijan kembali terjadi di wilayah Nagorno-Karabakh. Konflik tersebut terjadi pada 27 September 2020. Kedua negara saling menuduh memulai 
serangan terlebih dahulu. Di pihak Azerbaijan, Kementerian Pertahanan Azerbaijan menuduh bahwa pasukan Armenia telah melakukan serangan di luar Nagorno-Karabakh yakni Dashkesan. Sebaliknya, menurut pihak Armenia pasukan Azerbaijan yang terlebih dahulu melepaskan tembakan ke unit militernya di Kota Vardenis (Lisbet, 2020).

Azerbaijan dan Armenia secara historis telah bercampur tetapi memiliki etnis yang berbeda dan identitas agama (Azerbaijan sebagian besar Muslim, Armenia sebagian besar Kristen), dan mereka memilikiberjuang melawan konflik pahit di masa lalu. Sejarah politik dan demografis Nagorno-Karabakh diperebutkan dengan sengit. wilayah tersebutmayoritas penduduk etnis Armenia mengklaim kehadiran historis yang dominan di Nagorno-Karabakh. Azerbaijan dan Armenia terletak di wilayah Kaukasus Selatan, bersama dengan negara tetangga Georgia. Kaukasus Selatan adalah wilayah antara Laut Hitam dan Laut Kaspia yang terpisahdari Rusia oleh pegunungan Kaukasus Besar dan juga berbatasan dengan Iran dan Turki (Welt \& Bowen, 2021).

Namun jauh sebelum itu, Armenia dan Azerbaijan sudah terlibat konflik sejak lama. Armenia dan Armenia merupakan negara pecahan Uni Soviet. Kedua negara berjuang untuk menguasai Nagorno-Karabakh dan wilayah lainnya selama periode singkat kemerdekaan setelah Revolusi Bolshevik Rusia 1917. Armenia dan Azerbaijan dimasukkan ke dalam Uni Soviet pada 1920-1922 sebagai republik konstituen. Posisi Nagorno-Karabakh diberikan ke Azerbaijan Soviet pada tahun 1921 dan secara resmi didirikan dan dibatasi pada tahun 1923 sebagai bagian dari Uni Soviet hingga tahun 1991 (Welt \& Bowen, 2021).

Konflik yang berlangsung selama puluhan tahun antara Armenia dan Azerbaijan atas Nagorno-Karabakh meletus pada akhir September menjadi pertempuran terburuk yang pernah terjadi di daerah itu sejak perang etnis yang kejam pada 1990-an. Pertempuran telah menjadi hal biasa selama beberapa dekade di sepanjang garis depan Nagorno-Karabakh, yang diakui secara internasional sebagai bagian dari Azerbaijan tetapi merupakan rumah bagi etnis Armenia (Kramer, n.d.).

Pada tahun 1987, sengketa Nagorno-Karabakh meningkat menjadi perang antara Armenia dan Azerbaijan saat masih menjadi bagian dari Uni Soviet. Nagorno-Karabakh adalah bagian dari wilayah pegunungan yang diberikan kepada Azerbaijan dari Uni Soviet. Dari 1987-1991 
pogrom kekerasan dan kekuatan militer dilakukan di kedua sisi, dari 1992-1994 perang skala penuh meletus. Di tengah pertimbangan tekanan internasional dan 20.000 kematian, kekerasan dihentikan oleh perjanjian gencatan senjata yang ditengahi oleh Rusia pada tahun 1994. Gencatan senjata tahun 1994 adalah satu-satunya pencapaian diplomatik yang nyata terhadap resolusi konflik ini (Branch, 2018).

Nagorno-Karabakh secara resmi merupakan daerah otonom di dalam Azerbaijan. Menurut sensus 1989, wilayah ini memiliki populasi 189.000 (77\% Armenia, 22\% Azerbaijan). Konflik muncul pada tahun 1988, setelah penduduk Armenia di Nagorno-Karabakh berusaha untuk pindah yurisdiksi wilayah tersebut kepada Armenia. Otoritas Soviet menolak untuk menggambar ulang perbatasan, tetapi upaya dan mobilisasi massa berikutnya serta bentrokan kekerasan memicu konflik antara Armenia dan Azerbaijan di Nagorno-Karabakh. Konflik tersebut semakin meningkat pada tahun 1991, ketika pemerintah Soviet berusaha untuk melawan langkah-langkah menuju kemerdekaan oleh Armenia dan Azerbaijan, orang-orang Armenia di Nagorno-Karabakh mendeklarasikan kemerdekaan dari Azerbaijan, dan Azerbaijan menghapuskan status otonomi Nagorno-Karabakh (Welt \& Bowen, 2021).

Perang memaksa ratusan ribu orang meninggalkan rumah mereka. Etnis Azerbaijan pergi dan wilayah yang direbut oleh orang-orang Armenia, dan orang-orang Armenia melarikan diri dari wilayah Azerbaijan. Pada tahun-tahun berikutnya, para pihak mencoba untuk menyelesaikan pertanyaan tentang status Nagorno-Karabakh dalam pembicaraan tetapi gagal. Dalam pandangan Baku, resolusi berarti kembalinya wilayah yang memisahkan diri dari wilayah sekitarnya yang telah ditegaskan oleh Perserikatan Bangsa-Bangsa (PBB) di bawah hukum internasional untuk kontrolnya adalah Azerbaijan. Yerevan menginginkan kemerdekaan de jure untuk Nagorno-Karabakh, yang kemudian dapat memilih untuk bergabung dengan Armenia (Crisis Group Europe Briefing N91, 2020)

Ketika Uni Soviet runtuh pada 1991, wilayah Nagorno-Karabakh yang mayoritas beretnik Armenia, ingin melepaskan diri dari Azerbaijan sehingga pertepuran bersenjata pun pecah. Armenia mendukung gerakan tersebut sehingga terlibat konflik dengan Azerbaijan. Perang antara kedua negara itu tidak dapat dihindarkan hingga menelan korban tewas sekitar 30.000 jiwa. Pada 1993, Armenia berhasil menguasai Nagorno-Karabakh dan menduduki 20 persen wilayah Azerbaijan di sekitarnya. Nagorno-Karabakh dikendalikan oleh etnik separatis 
Armenia yang didukung oleh pemerintah Armenia. Pada 1994, Armenia dan Azerbaijan akhirnya mau menandatangai gencatan senjata yang ditengahi oleh Organization for Security and Co-operation in Europe atau Organisasi untuk Keamanan dan Kerja Sama di Eropa (OSCE) Minsk Group. OSCE Minsk Group merupakan komite yang dibentuk pada 1994 untuk menangani perselisihan dan diketuai bersama oleh Amerika Serikat, Rusia, dan Perancis. Namun, setelah itu, gencatan senjata tak selalu berjalan mulus. Ketegangan antara Armenia dan Azerbaijan di Nagorno-Karabakh masih terus belangsung. Hubungan yang panas antara kedua negara tersebut termanifestasi dalam sejumlah bentrokan pasukan tempur setelah 1994. Tercatat ada beberapa kali dilaporkan bentrokan kecil setelah tahun 2000-an. Terbaru, Azerbaijan dan Armenia bertempur dalam skala besar pada 2020 yang dimulai pada 27 September (Pristiandaru, n.d.).

Sejarah mencatat bahwasannya konflik Armenia dan Azerbaijan ini tidak terlepas dari perebutan wilayah yang telah diberikan oleh Uni Soviet. Nagorno-Karabakh menurut peta wilayah yang ditentukan oleh Uni Soviet merupakan bagian dari Azerbaijan. Namun karena wilayah tersebut dihuni oleh mayoritas etnis Armenia, maka Armenia menginginkan wilayah tersebut. Sengketa wilayah inilah yang kemudian memicu konflik-konflik berdarah yang merenggut korban jiwa.

Konflik Armenia dan Azerbaijan sendiri bukan tanpa penyelesaian. Resolusi konflik yang dimediasi oleh OSCE pada tahun 1994 merupakan jalan tengah menuju perdamaian. Namun pada pelaksanaannya gesekan-gesekan konflik pun terus terjadi. Hingga akhirnya memicu eskalasi konflik yang besar pada tahun 2020 .

\subsection{Kepentingan Turki}

Turki adalah negara yang mendukung Azerbaijan dalam konflik di Nagorno-Karabakh. Dukungan Turki tersebut tidak terlepas dari hubungan baik yang terjalin antara kedua negara. Turki merupakan mitra strategis terpenting Azerbaijan, dan kedua negara memiliki etnis yang dekat dan juga ikatan bahasa. Untuk mendukung Azerbaijan, Turki menutup perbatasan daratnya dengan Armenia pada tahun 1993, kemudian meninggalkan Armenia dengan akses darat ke Georgia di utara dan Iran di selatan (Welt \& Bowen, 2021). 
Dukungan Turki ini tentu saja merupakan keuntungan tersendiri bagi Azerbaijan. Di saat konflik sedang memanas, Turki menjadi garda terdepan dalam memberikan bantuan kepada Azerbaijan. Sikap Turki terhadap Azerbaijan tidak terlepas dari faktor politik antara Turki dan Armenia. Buruknya hubungan kedua negara membuka kesempatan bagi Turki untuk melancarkan kepentingan dengan turut serta dalam mendukung Azerbaijan yang merupakan seteru Armenia.

Hubungan Turki-Armenia semakin tegang oleh perselisihan internal era Perang Dunia yang mana Turki terlibat dalam kasus deportasi dan pembunuhan massal orang-orang Armenia di Kekaisaran Ottoman yang diakui Armenia sebagai genosida. Namun pemerintah Turki menolak tuduhan tersebut. Otoritas Turki sering menyatakan bahwa penarikan Armenia dari wilayah Azerbaijan adalah syarat untuk normalisasi hubungan. Pada tahun 2009, Armenia dan Turki meluncurkan proses pemulihan hubungan untuk membuka kembali perbatasan darat mereka dan memulihkan hubungan diplomatik (Welt \& Bowen, 2021).

Secara politik dan geostrategis, Turki masih bukan aktor utama untuk mengarsiteki kebijakan luar negeri di akhir era Soviet. Dua peristiwa menggambarkan kegagalan saat ini dalam ambisi kebijakan luar negeri Turki dan telah memaksanya untuk menjadi lebih bersikap realistis. Pertama, sebagai sekutu dekat Azerbaijan, Turki tidak banyak membantu menyelesaikan masalah konflik di Nagorno-Karabakh. Keberadaan Grup Minsk yang mana Turki tidak termasuk di dalamnya dan memiliki misi untuk mendorong kemajuan perdamaian antara Armenia dan Azerbaijan melalui jalur negosiasi sebagai resolusi konflik. Kedua, perang singkat di musim panas 2008 antara Rusia dan Georgia juga mengungkapkan penghapusan politik Turki di Kaukasus Selatan. Untuk memiliki hubungan baik dengan Rusia dan Georgia, Turki mencoba bermain peran sebagai mediasi dalam konflik tetapi itu tidak efektif (Balci, 2014).

Kedekatan Turki dan Azerbaijan tidak terlepas dari hubungan politik yang kuat, namun juga ada faktor budaya dan bahasa. Turki berusaha menciptakan konsep dua negara satu bangsa yang mana menghubungkan semua negara-negara yang berbahasa Turki. Azerbaijan adalah yang paling antusias dalam mengindahkan situasi ini. Hubungan bilateral yang baik adalah tidak terbatas pada interaksi pemerintah resmi, karena kedua masyarakat itu sangat erat 
dan saling terkait secara budaya. Banyak orang Turki berasal dari Azerbaijan, dan sejak akhir era Soviet ada peningkatan jumlah pernikahan antara orang Turki dan Azebaijan (Balci, 2014).

Kepentingan Turki dalam mendukung Azerbaijan tentu saja tidak lepas dari beberapa faktor. Pertama, Turki dan Azerbaijan memiliki hubungan politik yang kuat. Kedua, hubungan Turki dan Armenia yang renggang membuat Turki mengambil langkah mendukung Azerbaijan untuk mengalahkan Armenia. Ketiga, Turki ingin melakukan invasi budaya terhadap negara-negara yang berbahasa Turki, salah satunya adalah Azerbaijan. Dengan demikian, Turki akan memiliki negara mitra yang baik sehingga dapat mendukung kebijakan politik luar negeri dan eksistensi Turki di dunia Global.

\subsection{Kepentingan Rusia}

Rusia memiliki hubungan keamanan dan ekonomi yang kuat dengan Armenia. Banyak pengamat berpendapat bahwa Armenia telah mempertahankan hubungan semacam itu dengan Rusia karena kepercayaan luas di Armenia bahwa hanya Rusia yang dapat memberikan jaminan keamanan terhadap Azerbaijan dan Turki. Pada saat yang sama, banyak orang Armenia memiliki mempertanyakan sikap Rusia sebagai penjamin keamanan dan mitra ekonomi. Setelah perubahan pemerintahan di Armenia pada tahun 2018. Kepemimpinan politik negara mengejar demokrasi dan reformasi pemerintahan yang menempatkan ketegangan baru pada hubungannya dengan Rusia. Rusia menjamin keamanan Armenia melalui perjanjian kolektif dan bilateral. Kedua negara tersebut adalah anggota Collective Security Treaty Organization atau Organisasi Pakta Keamanan Kolektif (CSTO). Negara anggota CSTO berkomitmen untuk mempertahankan integritas teritorial anggota CSTO lainnya jika terjadi agresi. Rusia dan Armenia juga memiliki perjanjian bilateral yang mengikat pasukan Rusia yang ditempatkan di Armenia untuk menjamin keamanan bagi Armenia. Namun, komitmen ini tidak secara resmi mencakup Nagorno-Karabakh. Sebelum konflik yang terjadi pada 2020, para pengamat memperdebatkan apakah dan dalam situasi apa Rusia akan campur tangan secara terang-terangan jika permusuhan berlanjut (Welt \& Bowen, 2021).

Azerbaijan dan Rusia juga telah memelihara hubungan baik. Sejak tahun 1990-an, Azerbaijan telah dipimpin oleh pemerintah otoriter yang berusaha mempertahankan 
kemerdekaan dari Rusia. Pada pada saat yang sama, pemerintah-pemerintah ini telah meminta dukungan Moskow untuk menyeimbangkan situasi politik domestik dan tekanan internasional. Rusia adalah pemasok militer utama untuk Armenia dan Azerbaijan. Kedua negara memiliki akses untuk mengoperasikan peralatan Rusia dan peralatan era Soviet yang terus ditingkatkan, termasuk tank dan artileri. Sebelum perang musim gugur 2020, Rusia diduga mengejar kebijakan paritas sehingga tidak ada pihak yang akan mendapatkan keuntungan yang signifikan atas yang lain. Dengan melakukan itu, Rusia menyeimbangkan pembelian Azerbaijan atas persenjataan canggih dengan menyediakan senjata dan peralatan militer kepada Armenia dengan harga harga bersubsidi dan melalui pinjaman. Rusia telah memberi Armenia kemampuan canggih, seperti pesawat tempur SU-30 SM (Welt \& Bowen, 2021).

Hubungan Rusia dan Armenia memang berjalan cukup baik. meskipun pada tahun 2018 hubungan kedua negara sempat mengang, namunkeduanya masih merupakan anggota CSTO. Selain itu, Rusia memiliki perjanjian bilateral untuk memberikan jaminan keamanan kepada Armenia. Di sisi lain, Rusia juga memiliki hubungan yang baik dengan Azerbaijan. Rusia memiliki kepentingan untuk di bidang perekonomian terkait jual beli alat utama sistem persenjataan kedua negara. Rusia menjaga hubungan baik dengan kedua negara karena keduanya merupakan konsumen mereka. Sehingga, Rusia bermain dua kaki dalam menjaga hubungan dengan Armenia dan Azerbaijan.

\subsection{Rusia dan Resolusi Konflik di Nagorno-Karabakh}

Gencatan senjata yang terjadi antara Armenia dan Azerbaijan nampaknya mulai menemui titik terang. Rusia hadir sebagai mediator yang hendak menegahi konflik kedua negara tersebut. Pada tanggal 9 Oktober 2020, Menteri Luar Negeri Rusia, Sergey Victorovich Lavrov, bertemu dengan Menlu Azerbaijan Jeyhun Bayramov dan Menlu Armenia Zohrab Mnatsakanyan di Moskow. Pertemuan yang berlangsung selama lebih dari 10 jam ini merundingkan perjanjian kemanusiaan atas gencatan senjata Armenia dan Azerbaijan untuk menukar tawanan perang dan memulihkan keadaan yang dimulai pada tengah malam waktu setempat pada 10 Oktober. Baik Azerbaijan maupun Armenia tidak secara resmi mengakhiri gencatan senjata meskipun terjadi pelanggaran besar dengan korban sipil di kedua belah pihak. Armenia melaporkan penembakan Azerbaijan terhadap beberapa posisi di Nagorno-Karabakh, termasuk ibu kotanya Stepanakert. Azerbaijan melaporkan pelanggaran Armenia di berbagai 
posisi di dalamnya termasuk serangan rudal di kota terbesar kedua Azerbaijan, Ganja (Clark \& Yazici, 2020).

Upaya Rusia dalam memediasi kedua belah pihak yang terlibat konflik ini mendapat dukungan dari Prancis dan AS, yang bersama dengan Rusia menjadi ketua OSCE. Memfasilitasi negosiasi atas Nagorno-Karabakh, menengahi serangkaian tiga gencatan senjata kemanusiaan, merupakan tugas OSCE untuk menciptakan keamanan. Rusia akhirnya mampu menengahi gencatan senjata yang pada 9 November ketika Armenia berada di ambang kekalahan. Azerbaijan telah menguasai wilayah Shusha, sebuah kota di Nagorno-Karabakh yang dilihat kedua belah pihak sebagai tempat strategis dan bermakna secara historis (Crisis Group Europe Briefing N91, 2020).

Keberhasilan Rusia sebagai mediator konflik banyak dipuji karena mengakhiri perang antara Armenia dan Azerbaijan. Hasil tersebut merupakan sebuah pencapaian yang akan memungkinkannya untuk menjaga pasukan penjaga perdamaian di wilayah tersebut setidaknya selama lima tahun. Tetapi Rusia sekarang harus menjaga keseimbangan dalam hubungannya dengan Armenia dan Azerbaijan, tugas yang sulit mengingat status NagornoKarabakh tetap belum terselesaikan sepenuhnya. Meskipun pengaruh Moskow telah meningkat, demikian juga kerentanannya karena posisi pasukan penjaga perdamaian yang sama-sama dikuasai oleh Armenia Nagorno-Karabakh dan Koridor Lachin yang kritis, sekarang kembali di bawah kendali Azerbaijan yang menghubungkan wilayah yang disengketakan dengan Armenia (Bohlen, 2021).

Sikap Rusia yang maju sebagai penegah diantara konflik Armenia dan Azerbaijan tentu memberi keuntungan bagi mereka. Bukan hanya keuntungan secara politik semata, namun eksistensi mereka di mata dunia menjadi lebih terpandang. Rusia berhasil menengahi konflik dengan mengadakan perundingan di Moskow. Bagi Rusia, kesepakatan menghentikan gencatan senjata di Nagorno-Karabakh itu menegaskan peran utamanya di kawasan tersebut. Rusia bisa mengoptimalkan kapasitasnya untuk bertindak sebagai perantara. 


\section{KESIMPULAN}

Berdasarkan pemaparan di atas, dapat disimpulkan bahwa konflik yang terjadi antara Armenia dan Azerbaijan telah berlangsung sejak era 1990. Konflik tersebut diakibatkan oleh adanya sengketa wilayah Nagorno-Karabakh yang secara geografis menjadi milik Azerbaijan. Sebelum runtuh, Uni Soviet sudah membagi wilayah tersebut. Namun karena wilayah tersebut mayoritas dihuni oleh etnis Armenia, maka Armenia berusaha untuk menguasi wilayah Nagorno-Karabakh. Konflik yang berlangsung selama puluhan tahun antara Armenia dan Azerbaijan atas Nagorno-Karabakh meletus pada akhir September 2020. Konflik ini menjadi yang terburuk yang pernah terjadi di daerah itu sejak perang etnis yang kejam pada 1990-an. Dalam konflik yang terjadi antara Armenia dan Azerbaijan, terdapat peran serta Turki dan Rusia untuk mendapatkan kepentingan nasionalnya. Turki mendukung Azerbaijan dikarenakan mereka memiliki hubungan yang baik dalam hal politik, budaya dan bahasa. Selain itu, hubungan yang renggang antara Turki dan Armenia membuka celah bagi Turki untuk menekan Armenia melalui dukungan terhadap Azerbaijan. Di sisi lain, Rusia memiliki kepentingan untuk menjaga hubungan dalam menjamin keamanan bagi Armenia dan juga sebagai mitra ekonomi. Kemudian Rusia juga menjaga hubungan dengan Azerbaijan yang merupakan negara rekanan dan juga mitra ekonomi. Melihat situasi tersebut, Rusia bergerak menjadi penengah konflik dengan memediasi Armenia dan Azerbaijan di Moskow. Mediasi tersebut berhasil menghentikan gencatan senjata sehingga tidak ada lagi korban jiwa dari kedua belah pihak.

\section{DAFTAR PUSTAKA}

Bakry, Umar Suryadi. (2017). Dasar-Dasar Hubungan Internasional. Kencana: Depok.

Balci, Bayram. Strengths and Constraints of Turkish Policy in the South Caucasus. Insight Turkey, Vol. 16, No. 2, (43-52).

Branch, Anthony R. (2018) Armenia and the South Caucasus. Connections, Spring 2018, Vol. 17, No. 2, (47-60).

Célestine, Bohlen. (2021). Armenia's Postwar Crisis: What to Know. Council on Foreign Relations, (1-7). 
Clark, Mason and Ezgi Yazici. (2020). Erdogan Seeks to Upend Kremlin-Backed Status Quo in Nagorno-Karabakh. Institute for the Study of War, (1-3)

Crisis Group Europe Briefing N91. (2020). Improving Prospects for Peace after the NagornoKarabakh War. International Crisis Group, (1-18).

Ghaplanyan, Vardan. (2021). Armenia and Azerbaijan: High risk of cross-border violence in Nagorno-Karabakh despite ceasefire. Armed Conflict Location \& Event Data Project, (24-26).

Kartini, Kartono. (1996). Pengantar Metodologi Riset Nasional. Bandung: Mondari Maju.

Welt, Cory and Andrew S. Bowen. (2021). Azerbaijan and Armenia: The Nagorno-Karabakh Conflict. Congressional Research Service.

Kramer, Andrew E. Armenia and Azerbaijan: What Sparked War and Will Peace Prevail? from https://www.nytimes.com/article/armenian-azerbaijan-conflict.html

Lisbet. (2020). Konflik Armenia Dan Azerbaijan Serta Upaya Damai Masyarakat Internasional. Info Singkat, Vol. XII, No. 19, I/Puslit/Oktober/2020, 7-12.

Mardalis. (2008). Metode Penelitian: Suatu Pendekatan Proposal. Jakarta: Bumi Aksara.

Niou, Emerson M. S. and Peter C. Ordeshook. (1994). Alliances in Anarchic International Systems. International Studies Quarterly, Vol. 38, No. 2, pp. 167-191

Pristiandaru, Danur Lambang. [KALEIDOSKOP 2020] Perang Armenia-Azerbaijan di Nagorno-Karabakh dan Senjata yang Dipakai. from https://www.kompas.com/global/read/2020/12/12/140000970/-kaleidoskop-2020perang-armenia-azerbaijan-di-nagorno-karabakh-dan?page=all.

Sitepu, P. Anthonius. (2011). Studi Hubungan Internasional. Yogyakarta: Graha Ilmu. 